Working Paper

in Economics and

Development Studies

Department of Economics

Padjadjaran University

No. 200702

\title{
Regional Economic Integration and its Impacts on Growth, Poverty and Income Distribution: The Case of Indonesia*
}

Djoni Hartono

(University of Indonesia)

D.S. Priyarsono2

(Bogor Agriculture University)

Tien Dung Nguyen

(Ministry of Trade, Vietnam)

Mitsuo Ezaki

(Nagoya University)

March, 2007

Center for Economics and Development Studies, Department of Economics, Padjadjaran University Jalan Cimandiri no. 6, Bandung, Indonesia.

Phone/Fax: +62-22-4204510

http://www.lp3e-unpad.org 


\title{
Regional Economic Integration and its Impacts on \\ Growth, Poverty and Income Distribution: \\ The Case of Indonesia*
}

\author{
by \\ Djoni Hartono $^{1}$, D.S. Priyarsono ${ }^{2}$, \\ Tien Dung Nguyen ${ }^{3}$ and Mitsuo Ezaki ${ }^{4}$
}

March 2007

\begin{abstract}
Indonesia is facing the trade liberalization and regional economic integration with several free trade areas, i.e. bilateral FTA, regional FTA and multilateral FTA. The aim of this paper is to analyze the impact of those international relationships on Indonesian economic growth, poverty and income distribution. By using a Global Computable General Equilibrium (GCGE) model, we made eighteen simulations to analyze the current and the potential international relationship that is faced by Indonesia. Generally, Indonesia gains significant benefit in terms of real GDP, output and welfare except FTA with India. FTA also increases the household income of rural group higher than the urban group ones. Unskilled labor experiences more advantages than skilled labor and poor household gain more benefit than the rich household both in rural and urban areas. Those conditions imply that FTA potentially could be a solution for national poverty reduction.
\end{abstract}

\footnotetext{
* This research was financially supported by the Grant-in-Aid for Scientific Research (B) of the Japan Society for the Promotion of Sciences (JSPS) in the fiscal year 2006. The socio-economic survey of Indonesia was processed for the data base of our CGE modelling by Mr. Pipit Helly Sorayan (Staff at Indonesian Statistical Bureau), to whom we are grateful. Thanks go also to our assistant, Mr. Tony Irawan (Lecturer at Bogor Agricultural University).

${ }^{1}$ Faculty of Economics, University of Indonesia, Indonesia

${ }^{2}$ Faculty of Economics and Management, Bogor Agricultural University, Indonesia

${ }^{3}$ Research and Development Centre, Ministry of Trade, Vietnam

${ }^{4}$ Graduate School of International Development, Nagoya University, Japan.
} 


\section{INTRODUCTION}

ASEAN completed its summit meeting in Cebu City, the Philippines, on January 13, 2007. One important agreement signed in the meeting is the scheduling of formation of ASEAN Economic Community. For the Philippines, Indonesia, Malaysia, and Thailand, the Community will be effective in 2015. Vietnam, Khmer, Laos, and Myanmar will join the Community in 2020, where as Singapore and Brunei Darussalam will join initialize it in 2010 .

The initiative was prompted by a concern on a strong tendency of flow of investment to China and India as a form of economic competition between ASEAN and to these countries. It is planned that the Community will be similar to the European Economic Community that has become the European Union.

Beside the ASEAN Economic Community, Indonesia also faces the current and the potential international relationship such as APEC, WTO, ASEAN-China Free Trade Agreement (ACFTA), ASEAN+3 FTA, and some bilateral free trade agreements. Those agreements have impacts on Indonesian economy. The question that might be appeared is whether those agreements have or do not have advantages for Indonesian economy. Indonesian government has to consider the answer of the question above in order to formulate the international trade policy.

The recent development on international relations signifies the need of assessment of the regional economic integration. This study aims at the assessment, especially its impacts on economic growth, poverty, and income distribution, by using global computable general equilibrium (GCGE) approach.

Following this brief introduction, this paper discusses some current development of Indonesia's trade policy. It is then followed by an exploration on data of poverty and income distribution in Indonesia. The GCGE model specification and the simulation analysis will respectively be described in the fourth and fifth sections. Discussion on the result of the analysis will conclude this paper. 


\section{PATTERN OF INDONESIA'S TRADE POLICY}

Indonesian trade and investment policy have transformed substantially from a closed and protected regime to a more open one. Government has changed the strategy from an inward-looking substitution strategy to a more export-oriented economy. Recently, Indonesia is one of East Asian most liberal regimes but the road to this status has been long and winding.

Under the Soekarno administration, Indonesian economy had been much closed and protected. Then, it changed significantly when Soeharto came to power. The new government liberalized trade along with investment, dismantled import licensing, introduced new "export bonus" and simplified export-import procedure under a major trade policy package. The government also eliminated capital controls that become an important moment in Indonesia's capital account policy (Aswicahyono and Feridhanusetyawan, 2003).

After that, during the 1970s, oil price booming which stimulated economic growth made the government ignored trade liberalization reforms. Government increased protection and applied import substitution strategy. State-owned banks were intervened to provide subsidized credit for heavy industries through state-owned enterprises. Protection was even higher in the early 1980s when a new import system was introduced (Feridhanusetyawan, 2001).

In the mid 1980s, Indonesia made the first major trade reforms. The government lowered tariff ceiling to 60 percents, reduced the number of tariff level from 25 to 11 and converted several import licenses into tariff equivalents (DFAT, 2000). The simple average tariff was reduced from 27 percent in 1986 to 20 percent in 1991. The other reforms abolished import monopolies, simplified customs and outsourced substantial customs responsibilities.

Next, the simple average tariff rate remained steady and trade liberalization slowed in the early 1990s. The government applied the national car scheme and increased tariffs on 
some chemical product. Then, during the crisis 1997 , the simple average tariff rate on agricultural and industrial goods was stable at around 13 percent. Indonesian government decided not to close their selves off to the rest of the world and even accelerated trade liberalization under the IMF programs. The government also committed to removing all import licenses, eliminated non-tariff measures and introduced competition on agricultural products. However, Kim (2004) reveals that protections were increased in the some areas. The coverage of import prohibitions was increased from 7 to 27 tariff lines, while the coverage of import licensing was increased from 27 to 1,027 lines between 2001 and 2003.

Trade liberalization improved substantially in 1990s as a result of international commitments under AFTA, APEC and WTO. According to the Bogor Goals which is the result of APEC meeting in Bogor, developed countries have to apply free and open trade and investment by 2010. Meanwhile developing countries have to apply the same scheme by 2020. In 1995, Indonesian government itself committed to a schedule of tariff reductions that anticipated a maximum tariff rate of 10 percent by 2003 .

Currently, Indonesia adopts three strategies of international trade, i.e. supporting WTO agenda, promoting efforts on regional economic integration, and enhancing bilateral trade and economic cooperation. However, McGuire (2004) criticizes that actually Indonesia has no specific trade policy. Trade policies that are implemented are more reactive and $a d$ hoc rather than well-planning. The government only considers adjusting the tariff and non-tariff rate in facing international trade problems. Actually, the main problems in international trade occur behind the border trade rather than at the border trade, i.e. services sector deregulation, intellectual property right, etc.

There are four regional and multilateral agreements that are faced by Indonesia nowadays, namely AFTA, APEC, WTO and ASEAN-CHINA FTA. First, ASEAN countries agreed to form a free trade area among its members which is known as AFTA in 1992. Previously AFTA only consists of tariff reduction on some commodities including agricultural product which is politically sensitive. ASEAN members who have 
a tariff above $20 \%$ have to reduce it up to $20 \%$ and reduce it again up to $0-5 \%$ by the next ten years. Meanwhile, for ASEAN members who have a tariff below $20 \%$ have to reduce it up to $0-7 \%$ by the next 7 years. After that, agricultural products become the most complicated product to be negotiated because it really affects Indonesian economy and Philippines economy. Next, all members agreed that liberalization of agricultural product started on 2003 and have to finish by 2010. Even though, there were many significant improvements in AFTA implementation, some ASEAN members still have no motivation to fully open their market.

Second, APEC was established in 1989 with the objective to tighten economic cooperation between west part pacific countries and east part pacific countries. In the long term, APEC has an agenda to establish free and open trade and investment in Asia Pasific. There are three pillars that support APEC, i.e. liberalization of trade and investment; facilitate trade and investment; and cooperation in economy and technology. APEC encourages its members to establish unilateral cooperation to the non-APEC countries member rather than to establish regional cooperation among its members.

Third, WTO is a multilateral institution that was established on 1 January 1995 as a result of Uruguay Round. The main characteristic of Uruguay Round is its capability to encourage liberalization of agricultural product which is very sensitive among developing countries. Generally, Indonesian commitment in WTO can be grouped into 6 main topics. One of the main topics is the commitment on agriculture. Indonesia has agreed to reduce tariff as much as $10 \%$ for each commodity or about $24 \%$ for overall commodities which was started since 1994 and effective for ten years period.

The newest regional free trade area that is signed by Indonesia was ASEAN-China Free Trade Agreement (ACFTA). ACFTA was established on 4 November 2002 and will effective in the next ten years period. Tariff reduction has to start on 1 January 2005 until 2010 for ASEAN 6 (Brunei, Indonesia, Malaysia, Philippine, Singapore, Thailand) and China. Meanwhile, for the new members of ASEAN (Cambodia, Laos, Myanmar, and Vietnam), tariff reductions have to start on 1 January 2005 until 2015. 


\section{POVERTY AND INCOME DISTRIBUTION IN INDONESIA}

In this chapter we captured a short illustration of poverty and income distribution in Indonesia during 1996-2002 in terms of total poor household, gini coefficient and distribution of expenditure both in rural and urban areas. Gini coefficient is an indicator that could explain the condition of income distribution.

Table 1

Number and Percentage of Poor People in Indonesia, 1996-2005

\begin{tabular}{|r|r|r|r|r|r|r|}
\hline \multirow{2}{*}{ Year } & \multicolumn{2}{|c|}{ Number of Poor People (Million) } & \multicolumn{3}{|c|}{ Percentage of Poor People } \\
\cline { 2 - 7 } & Urban & \multicolumn{1}{c|}{ Rural } & \multicolumn{1}{c|}{ Total } & \multicolumn{1}{c|}{ Urban } & \multicolumn{1}{c|}{ Rural } & \multicolumn{1}{c|}{ Total } \\
\hline 1996 & 9.42 & 24.59 & 34.01 & 13.39 & 19.78 & 17.47 \\
\hline 1998 & 17.60 & 31.90 & 49.50 & 21.92 & 25.72 & 24.23 \\
\hline 1999 & 15.64 & 32.33 & 47.97 & 19.41 & 26.03 & 23.43 \\
\hline 2000 & 12.30 & 26.40 & 38.70 & 14.60 & 22.38 & 19.14 \\
\hline 2001 & 8.60 & 29.30 & 37.90 & 9.76 & 24.84 & 18.41 \\
\hline 2002 & 13.30 & 25.10 & 38.40 & 14.46 & 21.10 & 18.20 \\
\hline 2003 & 12.20 & 25.10 & 37.30 & 13.57 & 20.23 & 17.42 \\
\hline 2004 & 11.40 & 24.80 & 36.10 & 12.13 & 20.11 & 16.66 \\
\hline 2005 & 12.40 & 22.70 & 35.10 & 11.37 & 19.51 & 15.97 \\
\hline
\end{tabular}

Source: Statistics Indonesia, 2005.

Table 1 shows the total number and percentage of poor people in Indonesia both in rural and urban areas. During the crisis, the percentage of poor people in Indonesia increase moderately from $17.47 \%$ in 1996 to $24.23 \%$ in 1998 . However, the total percentages of poor people continuously decrease to $15.97 \%$ in 2005 . This condition implies that the macroeconomic condition in Indonesia was improved moderately. In the context of areas, the total number of poor people in rural areas was higher relative to urban areas. The average percentage of poor people in rural areas during the period 1996-2005 was 68.4\% relative to total poor people in nation and the highest percentage occurred in 2001 as much as $77.3 \%$. 
Table 2

Income Distribution in Indonesia 1996-2005: Gini Coefficient

\begin{tabular}{|c|c|c|c|}
\hline \multirow{2}{*}{ Year } & \multicolumn{3}{|c|}{ Gini Coefficient } \\
\cline { 2 - 4 } & Urban & Rural & U \& R \\
\hline 1996 & 0.362 & 0.274 & 0.356 \\
\hline 1999 & 0.326 & 0.244 & 0.311 \\
\hline 2002 & 0.317 & 0.247 & 0.288 \\
\hline 2005 & 0.338 & 0.264 & 0.343 \\
\hline
\end{tabular}

Source: Statistics Indonesia, 2005.

Next, Table 2 shows that the gini coefficient for urban area decreases from $0.362 \%$ in 1996 to $0.317 \%$ in 2002 and increases to $0.338 \%$ in 2005 . This implies that income distribution in urban areas was better in 2002 relative to 1996 and worse in 2005 . Meanwhile, income distribution in rural areas was better in 1999 and worse in the next two periods. Overall, income distribution in Indonesia has the same trend with income distribution in urban areas.

Table 3

Distribution of Expenditure in Urban and Rural Areas 1996-2005

\begin{tabular}{|l|l|l|l|l|}
\hline \multicolumn{1}{|c|}{ Area / Group } & 1996 & 1999 & 2002 & 2005 \\
\hline Urban & & & & \\
- Bottom 40\% & 19.03 & 20.52 & 21.34 & 20.38 \\
- Mid 40\% & 36.93 & 37.74 & 37.43 & 36.86 \\
- Top 20\% & 44.04 & 41.74 & 41.23 & 42.75 \\
\hline Rural & & & & \\
- Bottom 40\% & 23.18 & 24.59 & 24.97 & 24.19 \\
- Mid 40\% & 38.99 & 39.53 & 39.27 & 39.13 \\
- Top 20\% & 37.83 & 35.88 & 35.75 & 36.68 \\
\hline Urban \& Rural & & & & 21.84 \\
- Bottom 40\% & 20.25 & 21.50 & 22.83 & 37.73 \\
- Mid 40\% & 35.05 & 37.35 & 38.19 & 40.43 \\
\hline
\end{tabular}

Source: Statistics Indonesia, 2005. 
Expenditure distribution in terms of region and group can be shown in Table 3. In generally, most expenditure distribution was spent by 20 percent people who are categorized as a top group. In more specific framework, most expenditure distribution in rural areas was spent by 40 percent people who are categorized as a mid group. Whereas, in urban areas the most expenditure distribution was spent by 20 percent people who are categorized as a top group.

\section{THE MODEL SPESIFICATION}

The global CGE model in this paper is the global model that is developed by Nguyen and Ezaki (2005) to analyze the impacts of regional integration on Vietnam's economy. This model has been modified by using Indonesian data and Indonesian economic structure such as Input-Output (I-O), Social Accounting Matrix (SAM) and National Social Economic Survey in 2000. This model is developed along the lines with the GTAP world model (Hertel, 1997) to analyze a greater regional and industrial disaggregation, a detailed treatment of taxes and subsidies, international capital mobility and transportation costs. To run the model, we use GTAP database version 6.0 constructed for 2001.

We specified the global CGE model by using 20 industries and 16 regions. The regions consisted of all major economies in the region as well as the US, the EU and Oceania and focussed on East Asia. The emphasis of industrial activities are on the agricultural and manufacturing sectors, taking into consideration the diversified pattern of production and comparative advantage as well as the structure of protection in each individual country and region. The details of the regional and industrial classification are given in appendix A.

\section{Country models}

There are 16 country models in the global CGE model. These models are linked together through international trade and foreign investment. Generally, country models follow the standard neoclassical CGE model (Dervis et al, 1982). In this model, capital and labor are mobile across economic sectors with the assumption of full employment. Each country model has three production factors, i.e. capital, skilled labor and unskilled labor. These 
labor are combined in a Constant Elasticity of Substitution (CES) function to form a composite labor input. Whereas, the CES function of capital and composite labor form a sectoral output.

Nine kinds of taxes and subsidies were specified in each country model. It consists of tariffs, export duties, production taxes, capital and output subsidies, and sales taxes imposed on consumer goods, intermediate inputs and capital goods. Government revenue consists of revenues from all taxes and subsidies and allocated to savings and consumption in fixed proportions. The fixed expenditure shares of government real spending are used to define the government demand for final goods.

In the global CGE model, household income consists of labor and capital income. The household sector in Indonesia's model is disaggregated into 20 household groups according to the level of income, consisting of 10 urban groups and 10 rural groups. The aim of this disaggregation is to allow for a detailed inspection of the impact of trade liberalization on income distribution in Indonesia. The household consumption demand is determined using the Linear Expenditure System (LES) function. LES function is used because it can measure the effect of the change in income on the structure of consumption. People tend to spend less on agricultural goods and other necessities, and consume more manufacturing goods as their income rises.

The assumption of the external sector in country models is product differentiation, in which domestic and foreign goods are imperfect substitutes. Sectoral output is a Constant Elasticity of Transformation (CET) function of exports and domestically produced products. On supply side, domestic and foreign market supply is determined by the revenue maximization condition, depending on the relative prices at home and abroad. Meanwhile on the demand side, total domestic demand is satisfied through domestic production and imports, and the demand for imports and domestically produced goods is modeled using the Armington structure. 


\section{International Linkages}

As we mentioned above, country models are linked together through trade and investment flows. Domestic consumers and producers differentiate imports by sources, that is, imports coming from different countries are considered as imperfect substitutes and then modeled with the Armington structure. On the import side, total imports is a CES function of imports from different sources, and then the demand for imports from each sources is derived from the cost minimization condition. Meanwhile on the export side, exporters do not differentiate exports by countries of destination, that is, commodities supplied to foreign countries are seen as perfectly homogenous and are sold at the same price. In this model, that total exports supplied by home countries are equal to the sum of imports by foreign countries and imports from a country or region must be summed up to total exports by that country or region.

The transportation cost is calculated from the value of exports at f.o.b prices. On the demand side, the demand for transportation services for countries and regions is determined by the cost minimization condition based on the CES functional form. Therefore, the regional demand for transportation services will depend on the regional prices of transportation services, which are converted into a global currency unit using the corresponding exchange rates.

Trade and investment has been the topic in many empirical studies. Trade liberalization changes the relative prices of production factors, thereby affecting foreign capital inflows. Indeed, several studies have indicated that the change in capital inflows resulting from trade liberalization could produce considerable additional welfare gains. The relationship between trade and investment has been accounted for in some recent studies using CGE models, such as those by Lee and Mensbrugghe (2001) or Bchir et al. (2002). Both studies allocated investment or capital stock across regions and industries, depending on the rate of return to capital. The problems in these studies are the requirement of detailed information on foreign investment and capital at the sectoral level that is not available at the level of the industrial and regional disaggregation adopted in this paper. 
In the global CGE model, the simple approach that is discussed in Hertel (1997) is used to allow for international capital mobility. It assumed that the expected return on capital is decline with the addition to the capital stock at the rate determined by a flexibility parameter. Investment decisions are made in such a way that the rates of return on capital are equalized across countries and regions. Therefore, the change in global savings is allocated across country and regions to equalize the regional expected rates of return. In this approach, investment only partially adjusts in response to the changes in the rate of return caused by trade liberalization. The expected rate of return to capital is not very sensitive to the change in capital stock at a low value of the flexibility parameter. Therefore, in order to equalize the expected rate of return to capital, there has to be a large change in investment.

\section{Equilibrium Conditions}

In the equilibrium conditions, there are three aspects, i.e. the conditions in factor, commodity and foreign exchange markets. The assumption in factor market is full employment, and factor prices serve as equilibrating variables. In the labor market, total supply of skilled and unskilled labor is held fixed at the base-run level, and the labor market equilibrium determines wage rates. Capital rents adjust to maintain the equilibrium between the supply of and demand for capital in the capital market. Equilibrium in product markets equates the supply of domestic goods in each sector to the demand for domestically produced products, with domestic prices serving as equilibrating variables.

The fiscal balance is implied in the treatment of the government sector. Government consumption and savings are determined as fixed shares of government revenue. In the foreign exchange market, foreign savings adjust to the change in foreign investment inflows, and equilibrium is achieved through price adjustments. The model adopts a socalled savings-driven closure, in which total nominal investment is determined by available savings. The exchange rates are fixed for all countries and regions at the base run level. Under this approach, the domestic price level will change and cause the 
exchange rate to adjust in real terms to attain the equilibrium condition between the market supply of and the demand for foreign exchange.

\section{THE SIMULATION ANALYSIS}

\section{Data and the Model calibration}

We made use of GTAP database version 6.0 that is constructed for 2001 to run the model. ${ }^{1} 57$ industries and 87 regions originally specified in GTAP database are aggregated into 20 industries and 16 countries or regions in accordance with the model. We used GTAP data to calculate most of the parameters in the model, such as consumption shares, saving rates, tax rates, wage rates and capital rents. The elasticity of substitution in trade and production functions are taken from GTAP database, consisting of the elasticity of substitution between labour and capital, the elasticity of substitution between domestically produced goods and imports and the elasticity of substitution between imports from different sources. GTAP database gives high values to the elasticity in trade functions, while assigning relatively low values to the elasticity of substitution in production functions. Given the type of functions and the value of the elasticity, the scale and share parameters can be calculated directly from the benchmark data.

In Indonesia's model, household data is constructed using the socio-economic survey conducted by the Indonesian Statistical Bureau in 2000. The survey data is grouped into deciles according to income ranges, and each decile is further divided into urban and rural groups. Income of each labor type in twenty industries is obtained through total monthly income of members of households. Labor income is defined as wages and salaries, whereas capital income is profit from members of households' investment. Consumption data is based on household consumption expenditure on goods and services provided in the survey.

\footnotetext{
1 More details about GTAP database version 6 can be found in GTAP homepage (http://www.gtap.agecon.purdue.edu/).
} 
After that, the survey data is incorporated into GTAP by using a simple procedure. Next, it is used to compute income shares and to allocate the data on factor income for each household groups and industries. The expenditure shares are computed with the same procedure and are used to allocate GTAP data on private consumption to household groups. Data on household employment is also derived from the socio-economic survey 2000. This data is computed for each type of workers, i.e. skilled and unskilled workers, and is used to allocate employment data derived from GTAP database to household groups.

\section{Simulation scenarios}

We employed the CGE model described in the previous section to analyze the impacts of regional economic integration on Indonesia's economy. Eighteen simulation scenarios have been performed and are described briefly in Table 4 . These simulations are designed to cover all the major integration options that are currently faced by Indonesia, including the bilateral FTAs between Indonesia and China, Japan, EU, India, Korea, Singapore and the US. In addition, we also included in the simulation analysis the ASEAN free trade area (AFTA), China-ASEAN FTA, ASEAN+3 FTA, APEC free trade area, the possible formation of the East Asian free trade area and the global trade liberalization.

\section{Table 4}

\section{Simulation Scenarios}

\begin{tabular}{|ll}
\hline S0 & Base run \\
S1 & ASEAN FTA \\
S2 & China-ASEAN FTA \\
S3 & ASEAN + 3 FTA \\
S4a & East Asian FTA, removal of tariffs \\
S4b & East Asian FTA, removal of tariffs and agricultural subsidies \\
S5 & APEC FTA \\
S6 & Indonesia-China FTA, removal of tariffs \\
S7a & Indonesia -Japan FTA, removal of tariffs \\
S7b & Indonesia -Japan FTA, removal of tariffs and agricultural subsidies \\
S8a & Indonesia-US, removal of tariffs \\
S8b & Indonesia-US, removal of tariffs and agricultural subsidies \\
S9 & Indonesia-India, removal of tariffs \\
S10 & Indonesia-EU, removal of tariffs \\
S11 & Indonesia-Singapore, removal of tariffs \\
S12a & Indonesia-Korea, removal of tariffs \\
S12b & Indonesia-Korea, removal of tariffs and agricultural subsidies \\
S13 & Global Trade Liberalization
\end{tabular}


Tariff policy is not the only protection that is used by developing countries and industrial countries. They also applied non-tariff barriers and domestic subsidies and it often play a major role in protecting domestic industries. The current version of GTAP database provides detailed information on the tariffs and certain production subsidies in the form of output and capital subsidies. However, it does not quantify the tariff-equivalent effect of non-tariff barriers. Therefore, the simulation mainly focused on the removal of tariff barriers and quantified its impacts on Indonesian economy. There are two sets of simulations that are performed for the FTAs with developed countries like Japan, the US, Korea and the East Asian free trade area. The first set takes into account only the impacts of the tariff removal, while the second one quantifies the combined effect of removing both tariffs and agricultural subsidies.

\section{Macroeconomic Impacts of Economic Integration}

The result of simulations show that Indonesia gain significant benefit in terms of output and welfare in all free trade agreements types except agreement with India which has a negative impact on output and agreement with Singapore and Korea which only has a slight benefit on output. The benefit is really depending on the trading partner that is faced by Indonesia in free trade agreement.

According to Chaipan et al (2006) there are three sources in the CGE model that could explain the reasons of welfare and output gain. The first source is the level of protection prior to trade liberalization in the nation. The second source is trade liberalization in the nation's trading partners. The third source is the linkage between trade and investment. When trade liberalization is accompanied with an increase in investment, the latter would further stimulate growth through its impacts both on the supply and demand side.

The impact of AFTA on Indonesia economy was first investigated in simulation S1, in which we removed the tariffs imposed on bilateral trade between Indonesia and five major ASEAN countries, namely Vietnam, Malaysia, Singapore, Philippines and Thailand. The result indicates that trade liberalization in this region could bring significant gains for Indonesia. As shown in the simulation results, real GDP of Indonesia 
increase by $0.13 \%$, while the welfare index increase by $0.61 \%$. Unfortunately, the benefit on output and welfare is not as big as three other ASEAN members, namely Thailand, Vietnam and Malaysia which gain more significant benefit from AFTA liberalization.

One of the major reasons of economic integration in ASEAN is to improve the competitiveness of ASEAN countries and make them capable to compete with China and India in attracting foreign investment. It is interesting to see in S1 that, AFTA would significantly improve the investment environment in ASEAN countries, as reflected in the increasing of the return to capital across the region. Since the model allows for capital to partially adjust in response to the difference in the rate of return to capital, foreign investment would flow in ASEAN countries following AFTA liberalization. For Indonesia, the increase in real investment amounts to $1.22 \%$, largely compensating for the decline in government consumption and leading to an overall output gain. 
Table 5

Macroeconomic Impacts of Economic Integration on Indonesia (Percentage changes compared to the base-run)

\begin{tabular}{|c|c|c|c|c|c|c|c|c|c|}
\hline & S1 & $\mathrm{S} 2$ & S3 & $\mathrm{S} 4 \mathrm{a}$ & $\mathrm{S} 4 \mathrm{~b}$ & S5 & S 6 & S7a & S7b \\
\hline GDP deflator & 0.38 & 1.10 & 0.77 & 0.63 & 0.63 & 0.92 & 0.88 & -0.05 & -0.05 \\
\hline Consumer price index & 0.07 & 0.60 & 0.50 & 0.38 & 0.37 & 0.73 & 0.57 & -0.07 & -0.08 \\
\hline Wage rate of skilled labor & 0.75 & 1.76 & 1.26 & 1.15 & 1.12 & 1.65 & 1.27 & 0.16 & 0.12 \\
\hline Wage rate of unskilled labor & 0.79 & 1.84 & 1.78 & 1.66 & 1.66 & 2.53 & 1.31 & 0.44 & 0.44 \\
\hline Capital rent & 0.54 & 1.40 & 1.30 & 1.22 & 1.20 & 1.63 & 1.03 & 0.14 & 0.12 \\
\hline Real GDP & 0.13 & 0.26 & 0.08 & 0.05 & 0.04 & 0.28 & 0.20 & 0.04 & 0.03 \\
\hline Output & 0.23 & 0.48 & 0.23 & 0.18 & 0.16 & 0.55 & 0.37 & 0.13 & 0.11 \\
\hline Private consumption & 0.61 & 1.08 & 1.15 & 1.18 & 1.16 & 1.45 & 0.65 & 0.38 & 0.38 \\
\hline Government consumption & -2.27 & -4.26 & -10.48 & -11.49 & -11.52 & -11.63 & -2.01 & -4.37 & -4.40 \\
\hline Real investment & 1.22 & 3.02 & 3.83 & 3.84 & 3.86 & 4.34 & 2.28 & 1.81 & 1.83 \\
\hline Imports & 1.92 & 3.86 & 4.15 & 4.15 & 4.11 & 5.25 & 2.66 & 1.72 & 1.69 \\
\hline Exports & 0.68 & 1.28 & 1.63 & 1.67 & 1.62 & 2.30 & 0.85 & 0.79 & 0.74 \\
\hline Household income & 0.68 & 1.69 & 1.62 & 1.53 & 1.51 & 2.08 & 1.24 & 0.31 & 0.29 \\
\hline Labor income (skilled labor) & 0.75 & 1.76 & 1.26 & 1.15 & 1.12 & 1.65 & 1.27 & 0.16 & 0.12 \\
\hline Labor income (unskilled labor) & 0.79 & 1.84 & 1.78 & 1.66 & 1.66 & 2.53 & 1.31 & 0.44 & 0.44 \\
\hline Capital income & 0.64 & 1.64 & 1.59 & 1.52 & 1.50 & 1.96 & 1.20 & 0.27 & 0.26 \\
\hline Government revenue & -1.88 & -3.20 & -9.52 & -10.59 & -10.63 & -10.48 & -1.22 & -4.27 & -4.31 \\
\hline Welfare & 0.61 & 1.07 & 1.14 & 1.18 & 1.18 & 1.45 & 0.65 & 0.38 & 0.38 \\
\hline
\end{tabular}

Sources: Authors' calculation 
Table 5 (continued)

Macroeconomic Impacts of Economic Integration on Indonesia

(Percentage changes compared to the base-run)

\begin{tabular}{|l|r|r|r|r|r|r|rr|}
\hline & $\mathrm{S} 8 \mathrm{a}$ & $\mathrm{S} 8 \mathrm{~b}$ & $\mathrm{~S} 9$ & $\mathrm{~S} 10$ & $\mathrm{~S} 11$ & $\mathrm{~S} 12 \mathrm{a}$ & $\mathrm{S} 12 \mathrm{~b}$ & $\mathrm{~S} 13$ \\
\hline & & & & & & & \\
GDP deflator & 1.38 & 1.60 & 1.40 & 0.65 & -0.07 & 0.00 & 0.00 & 3.41 \\
Consumer price index & 1.12 & 1.32 & 0.39 & 0.41 & -0.07 & -0.08 & -0.08 & 2.80 \\
Wage rate of skilled labor & 2.08 & 2.00 & 0.88 & 1.14 & 0.00 & 0.11 & 0.11 & 4.51 \\
Wage rate of unskilled labor & 2.69 & 2.97 & 1.44 & 1.54 & 0.04 & 0.21 & 0.21 & 6.46 \\
Capital rent & 1.56 & 1.67 & 1.18 & 0.87 & -0.01 & 0.15 & 0.15 & 4.48 \\
Real GDP & 0.58 & 0.47 & -0.19 & 0.32 & 0.01 & 0.00 & 0.00 & 0.67 \\
Output & 0.78 & 0.57 & -0.33 & 0.50 & 0.04 & 0.01 & 0.00 & 1.31 \\
Private consumption & 0.92 & 0.92 & 0.89 & 0.77 & 0.08 & 0.29 & 0.29 & 2.65 \\
Government consumption & 0.37 & 0.14 & -0.96 & -2.12 & -1.04 & -2.87 & -2.88 & -14.35 \\
Real investment & 1.66 & 1.37 & 1.11 & 1.67 & 0.27 & 0.93 & 0.94 & 5.05 \\
Imports & 3.68 & 3.21 & 1.45 & 2.95 & 0.28 & 1.10 & 1.10 & 8.86 \\
Exports & 1.78 & 1.37 & -0.78 & 1.36 & 0.19 & 0.47 & 0.46 & 3.89 \\
Household income & 1.97 & 2.09 & 1.28 & 1.14 & 0.01 & 0.21 & 0.21 & 5.25 \\
Labor income (skilled labor) & 2.08 & 2.00 & 0.88 & 1.14 & 0.00 & 0.11 & 0.11 & 4.51 \\
Labor income (unskilled labor) & 2.69 & 2.97 & 1.44 & 1.54 & 0.04 & 0.21 & 0.21 & 6.46 \\
Capital income & 1.69 & 1.78 & 1.26 & 1.00 & 0.01 & 0.22 & 0.22 & 4.87 \\
Government revenue & 1.63 & 1.58 & 0.05 & -1.48 & -1.07 & -2.78 & -2.78 & -11.15 \\
Welfare & 0.92 & 0.92 & 0.89 & 0.77 & 0.08 & 0.29 & 0.29 & 2.64 \\
& \multicolumn{2}{|r|}{} & & & & & \\
\hline
\end{tabular}

Sources: Authors' calculation 
Simulation 2 is designed to analyze the economic impact of free trade agreement between China and ASEAN. The results show that the FTA increases the Indonesian real GDP by $0.26 \%$ and welfare by $1.07 \%$. This FTA also increases real investment by $3.02 \%$, export by $1.28 \%$ and import by $3.86 \%$. Meanwhile, free trade agreement between ASEAN, Japan, China, and Korea (ASEAN+3) has a different impacts on Indonesian economy. This FTA result an insignificant increase on real GDP about $0.08 \%$. However, this FTA substantially increases welfare, real investment, export and import by $1.14 \%, 3.83 \%$, $1.63 \%$ and $4.15 \%$ respectively. The impact of free trade agreement between countries which are member of ASEAN +3 can be shown on simulation 3 .

In simulation $4 \mathrm{a}$, we measured the impact of free trade agreement between countries in East Asian. Meanwhile, simulation $4 \mathrm{~b}$ explains the impact of FTA between countries in East Asian which is followed by the removal of agricultural subsidies in Japan and Korea. Both simulations show that the impact of the FTA is not significant where Indonesian real GDP only increase by $0.05 \%$ and $0.04 \%$ and real investment increase as much as $3.84 \%$ and $3.86 \%$. In terms of export and import, the results of both simulations are nearly similar. Moreover, both simulations result the same economic impact on welfare as much as $1.18 \%$.

Simulation 5 shows the impact of free trade agreement under APEC organization on Indonesian economy. APEC significantly increases welfare by $1.45 \%$, real investment by $4.34 \%$ and slight impact on real GDP by $0.28 \%$. Moreover, APEC also increases export and import as much as $5.25 \%$ and $2.30 \%$.

Next, simulation 13 shows the impact of free trade agreement between all countries which is known as Global Trade Liberalization on Indonesian economy. For Indonesia, welfare and real investment increase substantially by $2.64 \%$ and $5.05 \%$. Meanwhile, real GDP only increase slightly as much as $0.67 \%$. Global Trade Liberalization also increases export and import by $8.86 \%$ and $3.89 \%$. 
According to the result of seven simulations, we can conclude that the impact of regional FTA, namely ASEAN, China-ASEAN, ASEAN+3, EAST ASIAN, APEC and Global Trade Liberalization are insignificant. Its only increase real GDP by $0.04 \%-0.67 \%$. The most significant impact on real GDP is created by Global Trade Liberalization. On the other hand, the smallest impact on real GDP is created by East-Asian FTA. The impact of regional FTA on output also insignificant, its only increase output by $0.16 \%-1.31 \%$. The most significant impact is also created by Global Trade Liberalization.

In terms of real investment and welfare, most simulations show that regional FTA creates significant impact on both indicators, except ASEAN FTA which only increases welfare by $0.61 \%$. Similar with the impact on real GDP and output, Global Trade Liberalization also have the most significant impact on real investment and welfare.

Seven simulations above are designed to measure the economic impact of regional free trade agreement on Indonesian economy. In the next simulation, we measured the economic impact of bilateral agreement on Indonesian economy. First, in simulation 6 we analyzed the impact of free trade agreement between Indonesia and China.

The result of simulation 6 shows that the impact of free trade agreement with China on Indonesian economy is not really significant. Indonesian real GDP and welfare increase slightly about $0.20 \%$ and $0.65 \%$. Furthermore, this FTA raises real investment, export and import by $2.28 \%, 2.66 \%$ and $0.85 \%$ respectively.

Simulation 7a shows the implication of free trade agreement with Japan. Meanwhile, the impact of free trade agreement with Japan which is followed by the removal of agricultural subsidies is shown on simulation $7 \mathrm{~b}$. The results show that the benefit that could be gained by Indonesia is lower than the benefit from FTA with China. Under simulation 7a, Indonesian real GDP, real investment and welfare increase by $0.04 \%$, $1.81 \%$ and $0.38 \%$ respectively. Meanwhile, simulation $7 \mathrm{~b}$ shows that Indonesian real GDP, real investment and welfare increase by $0.03 \%, 1.83 \%$ and $0.38 \%$. To sum up, the result of simulation $7 \mathrm{a}$ and $7 \mathrm{~b}$ are nearly similar. 
Next, we analyze the implication of free trade agreement with US (simulation 8a) and the implication of free trade agreement with US which is followed by the removal of agricultural subsidies (simulation 8b). Simulation 8a shows that Indonesian real GDP, real investment and welfare raise moderately as much as $0.58 \%, 1.66 \%$ and $0.92 \%$. Whereas, simulation $8 \mathrm{~b}$ shows that Indonesian real GDP, real investment and welfare raise moderately as much as $0.47 \%, 1.37 \%$ and $0.92 \%$. Both simulations show the significant differences in terms of real GDP and real investment.

Simulation 9 is designed to measure the economic impact of free trade agreement with India. The results of this FTA differ to other free trade agreement because it decreases real GDP and output by $0.19 \%$ and $0.33 \%$. However this FTA increases real investment and welfare as much as $1.11 \%$ and $0.89 \%$.

Simulation 10 shows the implication of free trade agreement with EU on Indonesian economy. Indonesia could gain a better benefit with this FTA relative to other FTA. FTA with EU increases real GDP, real investment and welfare by $0.32 \%, 1.67$ and $0.77 \%$ respectively. On the other hand, FTA with Singapore (simulation 11) results a small benefit for Indonesian economy. It only raises real GDP, real investment and welfare as much as $0.01 \%, 0.27 \%$ and $0.08 \%$.

The implication of free trade agreement with Korea and the combination of FTA and the removal of agricultural subsidies can be seen on simulation 12a and 12b. Both simulations show that the FTA with Korea could not affect Indonesian real GDP. Moreover, in terms of real investment, both simulations increase real investment by $0.93 \%$ and $0.94 \%$. Both simulations also raise welfare by $0.29 \%$. To sum up, the implication of FTA with Korea in both simulations is not really different in terms of real investment and welfare and similar in terms of real GDP where the FTA does not affect real GDP.

In the context of bilateral FTA (country to country or country to regional), Indonesia gain the most significant benefit from Indonesia-US FTA. It increases real GDP and output by 
$0.47 \%-0.58 \%$ and $0.57 \%-0.78 \%$. Mean while, the opposite impact is created by the FTA between Indonesia and India which decrease Indonesian real GDP and output as much as $0.19 \%$ and $0.33 \%$.

Most simulations show that bilateral FTAs have significant impact on Indonesian real investment except bilateral FTA between Indonesia-Singapore and Indonesia-Korea. Bilateral FTAs increase real investment by $1.11 \%-2.28 \%$. Furthermore, most bilateral FTAs only have small impact on welfare. It only increases welfare by $0.08 \%-0.92 \%$. The most significant impact is created by the FTA between Indonesia and US. Meanwhile, the smallest impact is created by FTA between Indonesia and Singapore.

\section{Sectoral Impacts of Economic Integration}

In this chapter we will analyze the implication of free trade agreement on Indonesian economy especially sectors' output. The implication of FTA is really depending on the type of FTA itself. According to the results of simulations, the implication of FTA on output is not significant (simulation 12a, 12b and Indonesia-Korea) and in the one case have a negative impact to economy (simulation 9). The most significant positive impact on sectors' output can only be shown on simulation 5 (APEC) simulation 8 (IndonesiaUS) and simulation 13 (Global Trade Liberalization).

In the case of ASEAN (AFTA), FTA creates positive output growth on some sectors, such as automobile, other transport means, machine, metal and construction. However, this FTA also creates negative output growth on leather sector (simulation 1). Simulation 2 shows that the free trade agreement between ASEAN and China creates significant output growth on some sectors, namely forestry, wood, automobile, electronics, machine and construction. However it also creates significant negative output growth on some other sectors, such as sector mining, leather and other manufactures.

Free trade agreement under ASEAN +3 (simulation 3) and East Asian (simulation 4a and $4 b)$ are predicted create similar implications. The difference on the three simulations is only happen on textile sector where the decreasing of textile sector on simulation $4 \mathrm{a}$ and 
$4 \mathrm{~b}$ are more significant than simulation 3 . The results show that the sectors that gain significant positive growth are fishing, wood, electronics, machine and construction. Whereas, other sectors such as automobile, other transport means, metal, textile (simulation $4 \mathrm{a}$ and $4 \mathrm{~b}$ ), leather and other manufactures experience significant negative output growth.

Simulation 5 shows the implication of FTA under APEC organization on sectors' growth. In this simulation, some sectors such as crop, forestry, wood, machine, textile, leather and construction experience significant positive growth. Whereas, some other sectors such as mining, automobile, other transport means, metal and other manufactures could experience negative growth. In the case of bilateral agreement between Indonesia and China, some sectors such as forestry, wood, chemical, electronics and construction gain significant positive growth. Whereas, some others namely other transport means, metal, leather and other manufactures experience significant negative growth.

In the simulation $7 \mathrm{a}$ and $7 \mathrm{~b}$, free trade agreement between Indonesia and Japan creates significant positive growth on some sectors such as forestry, wood, machine, textile, leather and construction. Meanwhile, two other sectors namely automobile and metal experience negative growth.

The implication of free trade agreement between Indonesia and US which is not followed or followed by the removal of agricultural subsidies (simulation $8 \mathrm{a}$ and $8 \mathrm{~b}$ ) have similar impact with other FTA. Some sectors such as crop (simulation $8 \mathrm{~b}$ ), textile, leather and construction gain significant positive growth. Whereas, some other sectors, namely forestry, mining, wood, other transport means, electronics, machine, metal and other manufactures experience significant negative growth on.

The most different result could be found in simulation 9. According to the result of this simulation, free trade agreement between Indonesia and India creates negative growth on the most sectors in Indonesia except food processing, beverage and construction. The 
sectors that experience significant negative growth are forestry, wood, other transport means, electronics, machine, metal, textile, leather and other manufactures.

Simulation 10 shows the implication of free trade agreement between Indonesia and EU. Under this FTA, sectors that gain significant positive growth are textile, leather and construction. Whereas, the opposite result happen on some other sectors such as forestry, mining, wood, automobile, machine, metal and other manufactures. Simulation 11 to $12 \mathrm{~b}$, namely FTA with Singapore (simulation 11), FTA with Korea (simulation 12a) and FTA with Korea which is followed by the removal of agricultural subsidies (simulation 12b) create insignificant impact on sectors' output growth. However, in simulation 12a and $12 \mathrm{~b}$, there are two sectors, namely automobile and other manufactures experience significant negative growth.

Finally, in the last simulation (simulation 13), Global Trade Liberalization creates significant positive growth on some sectors, such as crop, fishing, food processing, machine, textile, leather and construction. On the other hand, this FTA also decrease the output of some other sectors namely mining, automobile, electronics, metal and other manufactures.

In conclusion, according to the results of all simulations, there are three sectors that are never experience negative growth as the implication of free trade agreement. Those sectors are fishing, beverage and construction. 
Table 6

Sectoral Impacts of Economic Integration on Indonesia (Percentage changes compared to the base-run)

\begin{tabular}{|c|c|c|c|c|c|c|c|c|c|}
\hline & $\mathrm{S} 1$ & $\mathrm{~S} 2$ & S3 & $\mathrm{S} 4 \mathrm{a}$ & S 4 b & S5 & S 6 & $\mathrm{~s} 7 \mathrm{a}$ & $\mathrm{S} 7 \mathrm{~b}$ \\
\hline Crop & -0.09 & -0.34 & 0.62 & 0.68 & 0.83 & 1.39 & -0.36 & 0.07 & 0.21 \\
\hline Livestock & 0.08 & 0.07 & 0.00 & 0.02 & 0.07 & -0.13 & 0.01 & 0.13 & 0.16 \\
\hline Forestry & -0.09 & 1.47 & 2.95 & 3.05 & 2.98 & 1.47 & 1.45 & 1.14 & 1.08 \\
\hline Fishing & 0.14 & 0.24 & 0.32 & 0.43 & 0.43 & 0.33 & 0.11 & 0.24 & 0.24 \\
\hline $\begin{array}{l}\text { Mining } \\
\text { Food }\end{array}$ & -0.61 & -1.23 & -0.44 & -0.22 & -0.23 & -1.56 & -0.99 & -0.45 & -0.47 \\
\hline processing & -0.05 & 0.02 & 0.15 & 0.19 & 0.23 & -0.07 & 0.05 & 0.24 & 0.27 \\
\hline Beverage & 0.88 & 0.73 & 0.62 & 0.61 & 0.61 & 0.55 & 0.06 & 0.01 & 0.01 \\
\hline Wood & -0.18 & 1.71 & 3.44 & 3.59 & 3.50 & 1.68 & 1.76 & 1.23 & 1.16 \\
\hline Chemical & -0.25 & 0.81 & 0.61 & 0.57 & 0.54 & 0.14 & 1.08 & -0.35 & -0.37 \\
\hline Automobile & 1.53 & 1.65 & -6.72 & -6.60 & -6.64 & -6.74 & 0.23 & -5.41 & -5.45 \\
\hline $\begin{array}{l}\text { Other } \\
\text { Transport }\end{array}$ & & & & & & & & & \\
\hline means & 8.41 & -0.71 & -1.29 & -1.22 & -1.28 & -1.77 & -5.01 & 0.86 & 0.83 \\
\hline Electronics & 0.13 & 3.35 & 2.42 & 2.68 & 2.45 & -0.44 & 4.78 & 0.84 & 0.69 \\
\hline Machine & 4.06 & 4.06 & 5.14 & 5.86 & 5.69 & 3.85 & -0.40 & 1.51 & 1.36 \\
\hline Metal & 1.00 & -0.96 & -2.68 & -2.59 & -2.72 & -4.65 & -2.44 & -2.10 & -2.21 \\
\hline Textile & 0.93 & 0.98 & -0.16 & -1.36 & -1.39 & 9.63 & 0.87 & 1.32 & 1.28 \\
\hline Leather & -1.07 & -5.22 & -2.97 & -4.04 & -4.01 & 7.05 & -4.18 & 6.64 & 6.60 \\
\hline Other & & & & & & & & & \\
\hline manufactures & -0.54 & -3.39 & -3.50 & -4.15 & -4.20 & -5.92 & -3.20 & -0.11 & -0.16 \\
\hline utility & 0.45 & 0.66 & 0.30 & 0.30 & 0.27 & 0.16 & 0.33 & -0.06 & -0.08 \\
\hline Construction & 1.07 & 2.65 & 3.29 & 3.29 & 3.31 & 3.73 & 2.00 & 1.57 & 1.58 \\
\hline Services & 0.05 & 0.03 & -0.75 & -0.83 & -0.85 & -0.76 & 0.07 & -0.25 & -0.27 \\
\hline
\end{tabular}

Sources: Authors' calculation 
Table 6 (continued)

Sectoral Impacts of Economic Integration on Indonesia

(Percentage changes compared to the base-run)

\begin{tabular}{|c|c|c|c|c|c|c|c|c|}
\hline & $\mathrm{S} 8 \mathrm{a}$ & $\mathrm{S} 8 \mathrm{~b}$ & S9 & $\mathrm{S} 10$ & $\mathrm{~S} 11$ & $\mathrm{~S} 12 \mathrm{a}$ & $\mathrm{S} 12 \mathrm{~b}$ & $\mathrm{~S} 13$ \\
\hline Crop & 0.09 & 2.01 & 1.78 & 0.24 & 0.02 & -0.04 & -0.01 & 4.20 \\
\hline Livestock & 0.21 & 0.27 & 2.36 & 0.44 & 0.02 & -0.01 & 0.01 & 0.93 \\
\hline Forestry & -2.76 & -3.29 & -2.46 & -1.44 & 0.12 & 0.44 & 0.42 & -0.72 \\
\hline Fishing & 0.20 & 0.20 & 1.86 & 0.25 & 0.02 & 0.05 & 0.05 & 1.19 \\
\hline $\begin{array}{l}\text { Mining } \\
\text { Food }\end{array}$ & -2.99 & -3.32 & 0.05 & -1.81 & -0.14 & 0.28 & 0.28 & -5.59 \\
\hline processing & 0.07 & 0.11 & 4.74 & 0.28 & 0.01 & 0.02 & 0.03 & 1.90 \\
\hline Beverage & 0.13 & 0.13 & 0.02 & 0.01 & 0.00 & 0.00 & 0.00 & 0.49 \\
\hline Wood & -3.49 & -4.09 & -3.28 & -1.87 & 0.11 & 0.50 & 0.48 & -0.95 \\
\hline Chemical & -0.64 & -0.97 & -0.41 & -0.71 & -0.36 & -0.03 & -0.04 & -0.91 \\
\hline $\begin{array}{l}\text { Automobile } \\
\text { Other } \\
\text { Transport }\end{array}$ & -0.35 & -0.58 & -0.42 & -2.15 & 0.02 & -2.60 & -2.61 & -8.99 \\
\hline means & -2.46 & -3.24 & -1.94 & 0.70 & 0.42 & 0.53 & 0.50 & -0.17 \\
\hline Electronics & -6.53 & -7.60 & -5.26 & -0.56 & 0.60 & 0.74 & 0.67 & -5.18 \\
\hline Machine & -4.15 & -5.08 & -2.84 & -1.60 & 0.47 & 0.63 & 0.62 & 1.47 \\
\hline Metal & -4.93 & -5.57 & -2.62 & -1.81 & 0.11 & -0.70 & -0.73 & -8.91 \\
\hline Textile & 14.87 & 14.22 & -3.36 & 8.86 & 0.33 & -0.07 & -0.07 & 30.17 \\
\hline $\begin{array}{l}\text { Leather } \\
\text { Other }\end{array}$ & 55.50 & 53.97 & -5.90 & 21.55 & 0.51 & 0.59 & 0.65 & 13.76 \\
\hline manufactures & -2.99 & -3.50 & -3.16 & -1.83 & 0.24 & -1.11 & -1.13 & -10.06 \\
\hline Utility & -0.10 & -0.30 & -0.26 & 0.18 & 0.04 & 0.03 & 0.02 & 0.16 \\
\hline Construction & 1.48 & 1.20 & 0.93 & 1.47 & 0.23 & 0.80 & 0.81 & 4.35 \\
\hline Services & 0.39 & 0.14 & -0.34 & 0.12 & -0.04 & -0.21 & -0.21 & -0.80 \\
\hline
\end{tabular}

Sources: Authors' calculation 


\section{Impacts on income distribution and poverty}

Chaipan et al (2006) reveals that the advantage of CGE models is that they could take into account the inter-industry linkage and the relative price changes, through which macroeconomic shocks are translated into microeconomic impacts. CGE models offer two channels, i.e. which trade liberalization and regional economic integration affects household welfare. First, trade liberalization cause changes in consumer prices. When

price decline, consumers will gain and they will lose otherwise. The impact of trade liberalization on consumer welfare is depending on the pattern of consumption.

The second channel translates factor incomes to the income of individual households. Trade liberalization has different impacts on factor remuneration as long as its impacts vary from industries to industries. The prices of the production factors that are intensively employed in the expanding industries would increase, and for those production factors involved mainly in the shrinking industries, the factor prices could decline. Households' income, production structure and factor prices will be affected differently by trade liberalization since households have different compositions of factor endowment

The implication of free trade and regional integration on Indonesian economy especially on household welfare may vary because it really depends on the trading partner country. Generally, free trade agreement could increase household income significantly except FTA with Japan (simulation 7a and 7b), FTA with Singapore (simulation 11) and FTA with Korea (simulation 12a and 12b). All simulations also show that unskilled labor income is higher than skilled labor income. The most significant case can be shown on simulation 3 (ASEAN+3), simulation 5 (APEC), simulation 8a and 8b (Indonesia-US), simulation 9 (Indonesia-India) and simulation 13 (Global Trade Liberalization).

In terms of average income that can be categorized as rural group and urban group, the results of simulations show that average household income for rural group is higher than urban group. This condition can be shown on simulation $3(\mathrm{ASEAN}+3)$, simulation $4 \mathrm{a}$ and 4b (East Asian), simulation 5 (APEC), simulation 7b (Indonesia-Japan with agricultural subsidies removal), simulation $8 \mathrm{a}$ and $8 \mathrm{~b}$ (Indonesia-US), simulation 9 
(Indonesia-India), simulation 10 (Indonesia-EU) and simulation 13 (global trade liberalization). On the other hand, the opposite condition happen on simulation 1 (ASEAN), simulation 2 (China-ASEAN), simulation 6 (Indonesia-China), simulation 11 (Indonesia-Singapore) and simulation 12a (Indonesia-Korea). Furthermore, some other simulations show that there is no gap between average household income on rural areas and urban areas, i.e. simulation $7 \mathrm{a}$ (Indonesia-Japan) and simulation $12 \mathrm{~b}$ (IndonesiaKorea with agricultural subsidies removal).

The most significant gap between average household income on rural areas and urban areas can be shown on simulation 13 (Global Liberalization Trade) and simulation 8 (Indonesia-US), where average household income on rural areas is higher than urban areas. This result is consistent because in the previous analysis we found that unskilled labor income is higher than skilled labor income.

In terms of average income gap between rich household and poor household who live in rural and urban areas, in general, poor household in urban areas gain higher benefit relative to rich household in urban areas except FTA between Indonesia and India (simulation 9) and Global Trade Liberalization (simulation 13). However, average income gap between rich household and poor household in urban areas is not significant and even the same in some simulation, namely FTA between Indonesia-Singapore and FTA between Indonesia-Korea.

Most simulations show that poor household in rural areas also gain higher benefit than rich household in rural areas, except simulation $8 \mathrm{~b}$ (Indonesia-US with agricultural subsidies removal) and simulation 9 (Indonesia-India). However, average income gap between rich household and poor household in rural areas is not significant and even the same in some simulation, namely AFTA (simulation 1), APEC FTA (simulation 5) and FTA between Indonesia-Singapore (simulation 11).

Next, we will analyze income inequality matters. According to average household income on rural areas and urban areas, AFTA FTA, China-ASEAN FTA, Indonesia- 
China FTA, Indonesia-Singapore and Indonesia-Korea (with agricultural subsidies removal) have created better income distribution on urban household relative to rural household. However, the gap is insignificant so income gap problem between urban and rural areas is not significantly increase.

Other simulations show that the increasing of income distribution on rural areas is higher than urban areas. However, the gap between income distribution on rural areas and urban areas is not significant except on simulation 5, simulation 8 and simulation 13. Those simulations indicate that income distribution is better for all household. In other words, there is a poverty reduction that will reduce income gap between urban and rural areas.

By using the previous analysis in this paper, we can reveal that agricultural subsidies removal by some countries could not create significant difference on the impact of free trade agreement in Indonesia. Furthermore, agricultural subsidies removal has no affect on income gap between urban areas and rural areas. 
Table 7

Impacts of Economic Integration on Indonesia's Household Income (Percentage changes compared to the base-run)

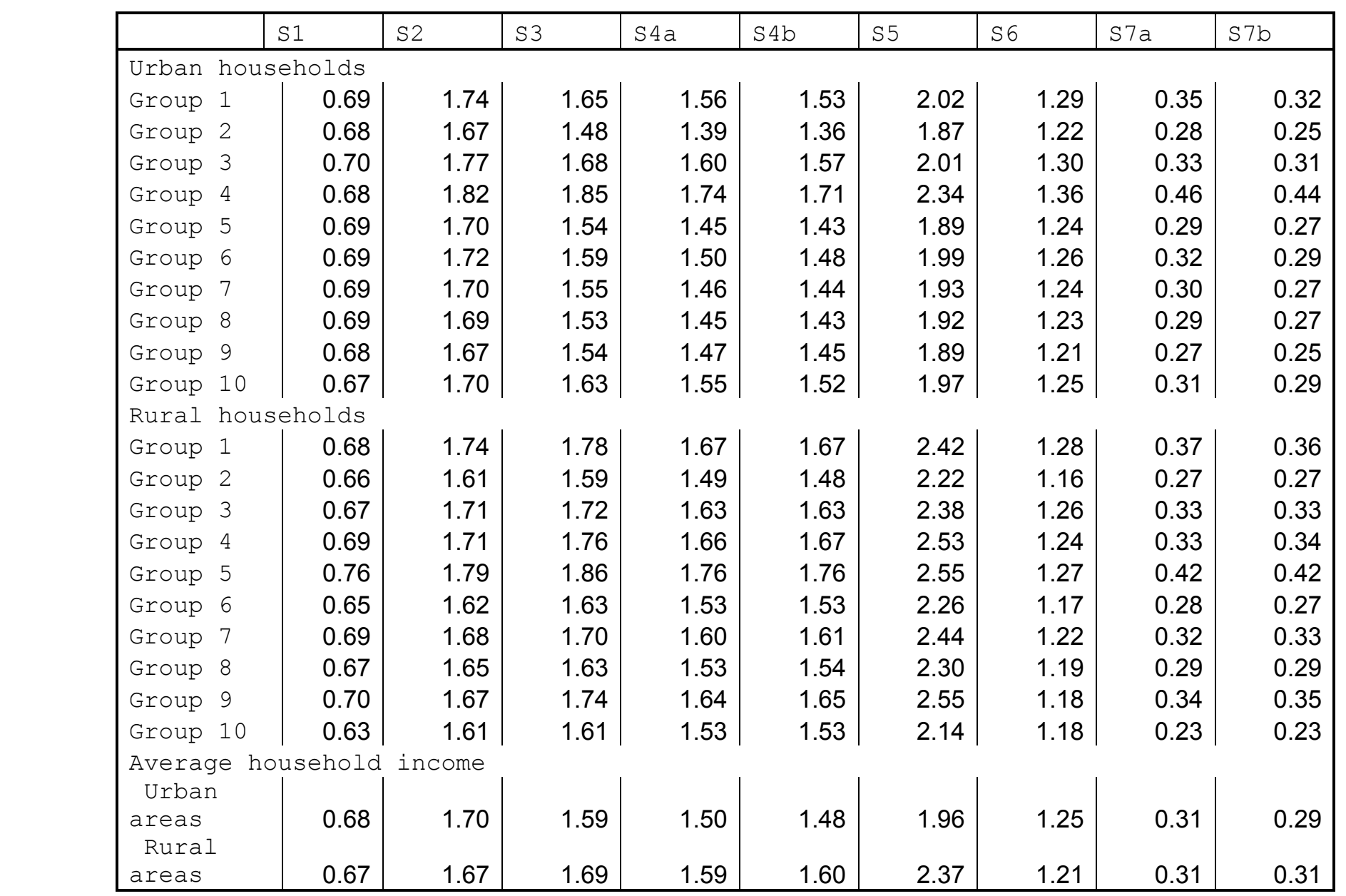

Sources: Authors' calculation 
Table 7 (Continued)

Impacts of Economic Integration on Indonesia's Household Income (Percentage changes compared to the base-run)

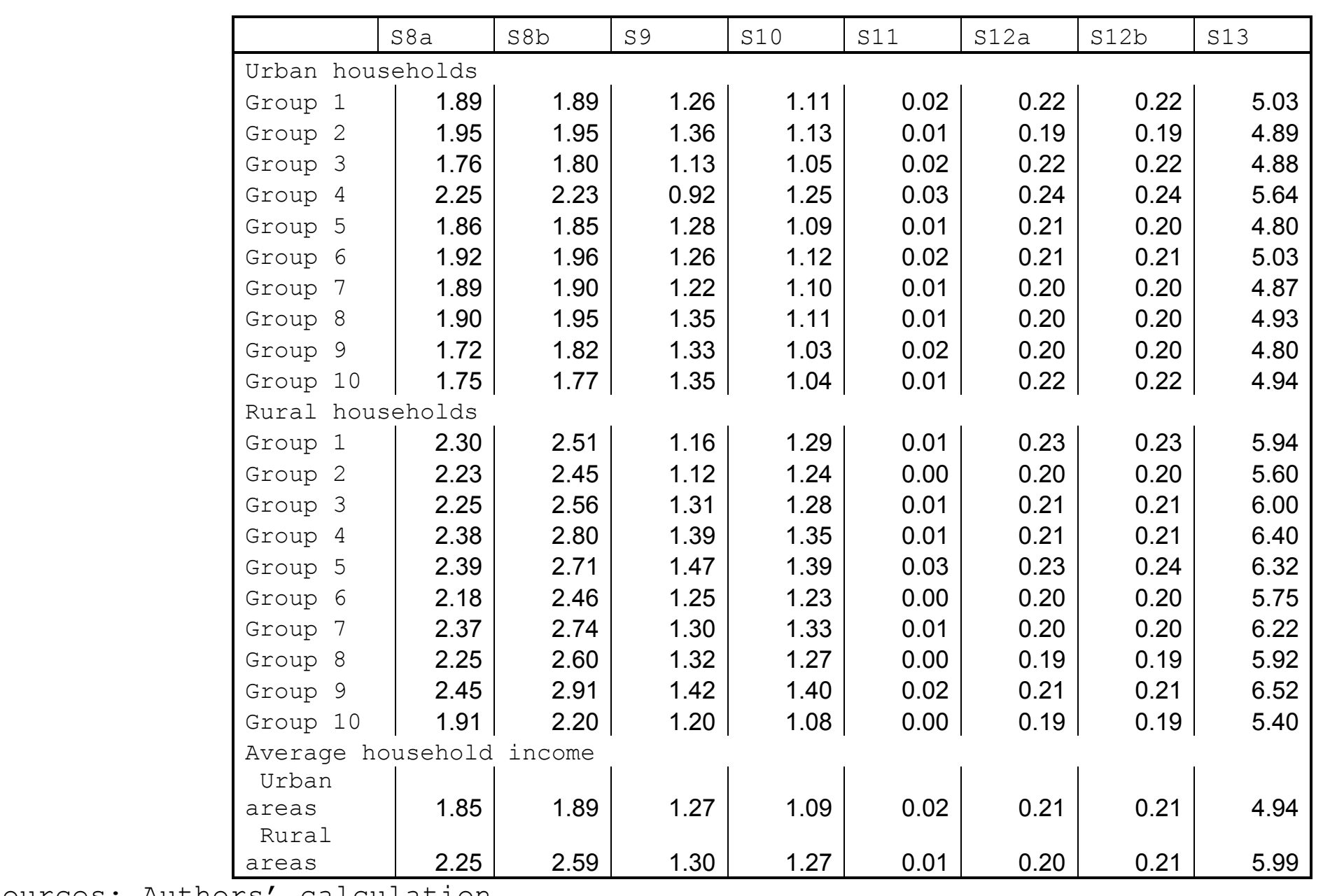

Sources: Authors' calculation 


\section{DISCUSSION AND CONCLUSION}

As mentioned in the previous chapter, we have constructed a global CGE model that specifies 20 industries and 16 regions to analyze the impacts of international relations, i.e. bilateral agreement, regional integration and global liberalization trade on economic growth, poverty and income distribution. Eighteen simulation scenarios have been

performed to analyze different economic integration option facing Indonesia, including the bilateral FTAs between Indonesia and China, Japan, EU, India, Korea, Singapore and the US. In addition, we also included the simulation analysis of the ASEAN free trade area (AFTA), China-ASEAN FTA, ASEAN+3 FTA, APEC free trade area, the possible formation of the East Asian free trade area and the global trade liberalization.

Generally, Indonesia gain significant benefit in terms of real GDP, output and welfare in all free trade agreements types except agreement with India which has a negative impact on real GDP and output. In the context of regional FTA, the significant impacts are created by global trade liberalization, APEC free trade area and China-ASEAN FTA. Question that might be appeared is why China-ASEAN FTA has more significant impact than ASEAN+3 FTA in which China is one of the member of ASEAN+3 FTA? This could be happened because the trade creations that are emerged in other ASEAN members as results of Japan and Korea join the ASEAN FTA. Trade creations emerged when other ASEAN members transfer their trading from Indonesia to Japan or Korea. However, when China joins ASEAN FTA, Indonesia still could compete with China products. It can be shown by the result of simulation 2 (China-ASEAN FTA) and simulation 6 (Indonesia-China FTA) in which Indonesian real GDP raise by $0.26 \%$ and $0.20 \%$. Therefore, China-ASEAN FTA is more favorable than ASEAN+3 FTA. Meanwhile, in terms of bilateral free trade agreement, Indonesia gains the most significant impact from Indonesia-US FTA, followed by Indonesia-EU FTA and Indonesia-China FTA.

The implication of free trade and regional integration on Indonesian economy especially on household welfare may vary because it really depends on the trading partner country. 
In general, free trade agreement increases household income significantly except FTA with Japan (simulation 7a and 7b), FTA with Singapore (simulation 11) and FTA with Korea (simulation 12a and 12b). All simulations also show that unskilled labor income is higher than skilled labor income. The most significant case can be shown on simulation 3 (ASEAN+3), simulation 5 (APEC), simulation 8a and 8b (Indonesia-US), simulation 9 (Indonesia-India) and simulation 13 (Global Trade Liberalization).

In terms of average income that can be categorized as rural group and urban group, the results of simulations show that average household income for rural group is higher than urban group. This condition can be shown on simulation 3 (ASEAN+3), simulation 4a and 4b (East Asian), simulation 5 (APEC), simulation 7b (Indonesia-Japan with agricultural subsidies removal), simulation $8 \mathrm{a}$ and $8 \mathrm{~b}$ (Indonesia-US), simulation 9 (Indonesia-India) and simulation 10 (Indonesia-EU). On the other hand, the opposite condition occur on simulation 1 (ASEAN), simulation 2 (China-ASEAN), simulation 6 (Indonesia-China), simulation 11 (Indonesia-Singapore) and simulation 12a (IndonesiaKorea). Furthermore, some other simulations show that there is no impact on gap between average household income on rural areas and urban areas, i.e. simulation $7 \mathrm{a}$ (Indonesia-Japan) and simulation 12b (Indonesia-Korea with agricultural subsidies removal).

The most significant gap between average household income on rural areas and urban areas can be shown on simulation 13 (Global Liberalization Trade) and simulation 8 (Indonesia-US) where average household income on rural areas is higher than urban areas. This result is consistent because in the previous analysis we found that unskilled labor income is higher than skilled labor income. Furthermore, this result implies that the income gap between household on rural and urban areas decline and potentially could reduce poverty level.

In the more specific framework, poor household gain higher benefit relative to rich household both in rural and urban areas except FTA between Indonesia and India (simulation 9) and Global Liberalization Trade (simulation 13) for rural and simulation 
$8 \mathrm{~b}$ (Indonesia-US with agricultural subsidies removal) and simulation 9 (Indonesia-India) for urban. However, average income gap between rich household and poor household in rural and urban areas are not substantial and even the same in some simulation, namely FTA between Indonesia-Singapore and FTA between Indonesia-Korea. Even though the impact is not significant, these results are still possibly used as indicator to conclude that FTA potentially could reduce poverty level. Furthermore, the results also emphasize the prior conclusion that FTA declines the income gap between household on rural and urban areas.

According to the sectoral impact of economic integration on Indonesia, agriculture and labor intensive industry such as textile and leather gain the most benefit relative to other sectors. These sectors are potential to gain more significant positive impact if the sectors have better performance. Therefore, government has to improve the competitiveness of these sectors by issuing policies that will attract investment and increase the quality of its human resources. 


\section{REFERENCES}

Aswicahyono, H. and Feridhanusetyawan, T. 2003. Indonesia's Strategy for industrial upgrading, paper presented at a workshop on "Why Trade and Industry Policy Matters", UNSFIR, Jakarta, 14 -15 January.

Bchir, M. H., Y. Decreux, J. L. Guerin and S. Jean. 2002. MIRAGE: A Computable General Equilibrium Model for Trade Policy Analysis. CEPII working Paper No. 2002-17.

BPS (Indonesian Statistical Bureau). 2001. National Social Economic Survey (SUSENAS), Statistical Publication, Jakarta.

Chaipan, C, T. D. Nguyen, and M. Ezaki. 2006. Regional Economic Integration and its Impacts on Growth, Poverty and Income Distribution: the Case of Thailand, Review of Urban \& Regional Development Studies.

Dervis, K., J. de Melo, and S. Robinson. 1982. General Equilibrium Models for Development Policies. A World Bank Research Publication, Cambridge University Press.

DFAT (Australian Department of Foreign Affairs and Trade). 2000. Indonesia: Facing the Challenge, DFAT East Asia Analytical Unit, www.dfat.gov.au

Feridhanusetyawan, T. 2001. Indonesia's trade policy and performance, Centre for Strategic and International Studies Working Paper, Jakarta.

Hertel, T.W. (ed.). 1997. Global Trade Analysis: Modeling and Applications, Cambridge University Press.

Kim, C. 2004. Industrial development strategy for Indonesia: Lessons from the Korean experience, paper presented at a workshop on "Why Trade and Industry Policy Matters", UNSFIR, Jakarta, 14-15 January.

Lee, H. and D. van der Mensbrugghe. 2001. A General Equilibrium Analysis of the Interplay between Foreign Direct Investment and Trade Adjustments. ICSEAD Working Paper Series Vol. 2001-18

McGuire, G. 2004. A Future Trade Policy for Indonesia: Which road to take? UNSFIR Working Paper Series No. 04/02, UNSFIR, Jakarta. 
Nguyen, T.D. and M. Ezaki. 2005. Regional Economic Integration and its Impacts on Growth, Poverty and Income Distribution: The Case of Vietnam, Review of Urban \& Regional Development Studies, Vol.17, No.3, November, pp.197-215.

. 2005. Regional Economic Integration and Its Impacts on Growth, Poverty and Income Distribution: The Case of Vietnam. Discussion Paper No. 132, GSID, Nagoya University, March.

Wang, F. and M. Ezaki. 2006. Regional Economic Integration and Its Impacts on Growth, Poverty and Income Distribution: The Case of China. Discussion Paper No. 144, GSID, Nagoya University, August. 


\section{Appendix A: Regional and Industrial Classification}

Table A1: Regional Mapping

\begin{tabular}{|l|l|}
\hline Regions and Countries & \multicolumn{1}{|c|}{ Description } \\
\hline 1. Vietnam & Vietnam \\
2. Indonesia & Indonesia \\
3. Malaysia & Malaysia \\
4. Philippines & Philippines \\
5. Thailand & Thailand \\
6. Singapore & Singapore \\
7. China & China \\
8. Korea & Korea \\
9. Hong kong & Hong kong \\
10. Taiwan & Taiwan \\
11. Japan & Japan \\
12. India & India \\
13. Oceania & Australia, New Zealand and other Oceania countries \\
14. The United of States & The United States \\
15. European Union & Austria, Belgium, Denmark, Finland, France, Germany, \\
\multicolumn{2}{|c|}{ England, Greece, Ireland, Italia, Luxemburg, Netherlands, } \\
16. Rest of the World & Portugal, Spain, Sweden \\
\hline
\end{tabular}




\section{Table A2: Industrial Mapping}

\begin{tabular}{|l|l|}
\hline \multicolumn{1}{|c|}{ Industries } & \multicolumn{1}{c|}{ Description } \\
\hline 1. Crop & $\begin{array}{l}\text { Paddy rice, wheat, cereal grains nec, vegetable, fruit, nuts, } \\
\text { oil seeds, sugar cane, sugar beet, plant-based fibers, other } \\
\text { crops }\end{array}$ \\
\hline 2. Livestock & $\begin{array}{l}\text { Cattle, sheep, goats, horses, other animal products, raw } \\
\text { milk, wool, silk-worm, cocoons }\end{array}$ \\
\hline 3. Forestry & Forestry \\
\hline 4. Fishing & Fishing \\
\hline 5. Mining & Coal, oil, gas, other minerals \\
\hline 6.Food processing & $\begin{array}{l}\text { Processed meat, vegetable, oils and fats, diary products, } \\
\text { processed rice, sugar, other food products }\end{array}$ \\
\hline 7. Beverages & Beverages and tobacco products \\
\hline 8. Wood & Wood products, paper, publishing \\
\hline 9. Chemical. & $\begin{array}{l}\text { Petroleum, coal product, chemical products, plastic } \\
\text { products, rubber, other mineral products }\end{array}$ \\
\hline 10. Automobile & Motor vehicles and parts \\
\hline $\begin{array}{l}\text { 11. Other transportation } \\
\text { means }\end{array}$ & Transportation equipments nec \\
\hline 12. Electronics & Electronic equipments \\
\hline 13. Machinery & Other machinery and equipment \\
\hline 14. Metal & Ferrous and non-ferrous metals \\
\hline 15. Textiles & Textiles and wearing apparel \\
\hline 16. Leather & Leather products \\
\hline 17. Other manufactures & Other manufactures \\
\hline 18. Utility & Electricity, gas manufactures and distribution, water \\
\hline 19. Construction & Construction \\
\hline 20. Services & Public and private services \\
\hline & \\
\hline
\end{tabular}




\section{Appendix B: The Global CGE Model}

\section{B1. Equations of the Model}

\section{Price Relations}

(1) $P M S_{i r k}=P M \$_{i k} \times E R_{r} \times\left(1+t m_{i r k}\right)$

(2) $P M_{i r}=a_{S_{i r}}{ }^{-1}\left(\sum_{k} \omega_{S_{i k k}}{ }^{1 /\left(1+\theta_{i r}\right)} P M S_{i r k}^{\theta_{i r} /\left(1+\theta_{i r}\right)}\right)^{\left(1+\theta_{i r}\right) / \theta_{i r}}$ where $M_{i r} P M_{i r}=\sum_{k} M S_{i r k} P M S_{i r k}$

(3) $\quad P E_{i r}=P E \$_{i r} \times E R_{r} \times\left(1+t e_{i r}\right)$

(4) $P_{i r}=a_{M_{i r}}{ }^{-1}\left(\omega_{M_{i r}}{ }^{1 /\left(1+\delta_{i r}\right)} P M_{i r}^{\delta_{i r} /\left(\delta_{i r}+1\right)}+\left(1-\omega_{M_{i r}}\right)^{1 /\left(1+\delta_{i r}\right)} P D_{i r}^{\delta_{i r} /\left(\delta_{i r}+1\right)}\right)^{\left(\delta_{i r}+1\right) / \delta_{i r}}$ where $P_{i r} Q_{i r}=P M_{i r} M_{i r}+P D_{i r} D_{i r}$

(6) $\quad W M_{i r}=a_{L_{i r}}{ }^{-1}\left(\sum_{l} \omega_{L_{l i r}}{ }^{1 /\left(1+\lambda_{i i r}\right)} W K M_{\text {lir }}^{\lambda_{i r} /\left(\lambda_{i r}+1\right)}\right)^{\left(\lambda_{i r}+1\right) / \lambda_{i r}}$

$P X_{i r}=a_{E_{i r}}{ }^{-1}\left(\omega_{E_{i r}}{ }^{1 /\left(1-\gamma_{i r}\right)} P E_{i r}^{\gamma_{i r} /\left(\gamma_{i r}-1\right)}+\left(1-\omega_{E_{i r}}\right)^{1 /\left(1-\gamma_{i r}\right)} P D_{i r}^{\gamma_{i r} /\left(\gamma_{i r}-1\right)}\right)^{\left(\gamma_{i r}-1\right) / \gamma_{i r}}$ where $P X_{i r} X_{i r}=P E_{i r} E_{i r}+P D_{i r} D_{i r}$

(7) $P V A_{i r}=P X_{i r}\left(1-t p_{i r}\right)-\sum_{j} i o c f_{i j r} P N M_{j r}$

(8) PINDEX $X_{r}=\sum_{i} c p c f_{i r} \times P_{i r}$

\section{Definition of Market Prices}

(9) $\quad P C M_{i r}=P_{i r}\left(1+t c_{i r}\right)$

(10) $P G M_{i r}=P_{i r}\left(1+\operatorname{tg}_{i r}\right)$

(11) $P N M_{i j r}=P_{i r}\left(1+t n_{i j r}\right)$

(12) $P K M_{i r}=P_{i r}\left(1+t k_{i r}\right)$

(13) $W K M_{\text {lir }}=W K_{\text {lir }}\left(1+t w_{\text {lir }}\right)$

(14) $R M_{i r}=R_{i r}\left(1+t r_{i r}\right)$ where $W M_{i r} L_{i r}=\sum_{l} W K M_{l i r} L K_{l i r}$

\section{Production and factor demand}

(15) $X_{i r}^{S}=a_{X_{i r}}\left(\omega_{X_{i r}} L_{i r}^{-\rho_{i r}}+\left(1-\omega_{X_{i r}}\right) K_{i r}^{-\rho_{i r}}\right)^{-1 / \rho_{i r}}$

(16) $L_{i r}=a_{X_{i r}}-\rho_{i r} /\left(1+\rho_{i r}\right)\left(\omega_{X_{i r}} P V A_{i r} / W M_{i r}\right)^{1 /\left(1+\rho_{i r}\right)} \times X_{i r}^{S}$

(17) $L K_{l i r}=a_{L_{i r}}{ }^{-\lambda_{i r} /\left(1+\lambda_{l i r}\right)}\left(\omega_{L_{l i r}} W M_{i r} / W K M_{l i r}\right)^{1 /\left(1+\lambda_{i r}\right)} \times L_{i r}$ where $L_{i r}=a_{L_{i r}}\left(\sum_{l} \omega_{L_{l i r}} L K_{l i r}^{-\lambda_{i r}}\right)^{-1 / \lambda_{i r}}$

(18) $W K_{\text {lir }}=$ wagecf $_{l i r} W K_{l r}^{e}$, here wagecf $_{\text {lir }}=$ constant

(19) $K_{i r}=a_{X_{i r}}-\rho_{i r} /\left(1+\rho_{i r}\right)\left(\left(1-\omega_{X_{i r}}\right) P V A_{i r} / R M_{i r}\right)^{1 /\left(1+\rho_{i r}\right)} X_{i r}^{S}$

(20) $R_{i r}=\operatorname{rentcf}_{l i r} R_{r}^{e}$, here rentcf $_{i r}=$ constant 


\section{Supply}

(21)

$$
\begin{gathered}
D_{i r}^{S}=a_{E_{i r}} \gamma_{i r} /\left(1-\gamma_{i r}\right)\left(\left(1-\omega_{E_{i r}}\right) P X_{i r} / P D_{i r}\right)^{1 /\left(1-\gamma_{i r}\right)} \times X_{i r}^{S} \\
\text { where } \\
X_{i r}=a_{E_{i r}}\left(\omega_{E_{i r}} E_{i r}^{\gamma_{i r}}+\left(1-\omega_{E_{i r}}\right) D_{i r}{ }_{i r}^{\gamma_{i r}}\right)^{1 / \gamma_{i r}}, \\
E_{i r}=a_{E_{i r}} \gamma_{i r} /\left(1-\gamma_{i r}\right)\left(\omega_{E_{i r}} \times P X_{i r} / P E_{i r}\right)^{1 /\left(1-\gamma_{i r}\right)} \times X_{i r}^{S},
\end{gathered}
$$

\section{Income and saving}

$$
\begin{aligned}
& Y H_{r}=\sum_{i} K_{i r} \times R_{i r}+\sum_{l i} L K_{l i r} \times W K_{l i r} \\
& Y H_{h r}=\left(\sum_{i} y k c f_{h i r} \times R_{i r} \times K_{i r}+\sum_{i} y l c f_{h l i r} \times W K_{l i r} \times L K_{l i r}\right) \\
& \text { for } r=\text { Indonesia }
\end{aligned}
$$

$$
\begin{aligned}
Y G_{r}= & \sum_{i} t p_{i r} P X_{i r} X_{i r}+\sum_{i} t c_{i r} P_{i r} C_{i r}+\sum_{i} t g_{i r} P_{i r} G_{i r}+ \\
& \sum_{i j} t n_{i j r} P_{i r} i o c f_{i j r} X_{j r}+\sum_{i} t k_{i r} P_{i r} I D_{i r}+ \\
& \sum_{i k} t m_{i r k} P M \$_{i r k} M S_{i r k} E R_{r}+\sum_{i} t e_{i r} P E_{i r} E_{i r}+ \\
& \sum_{l i} t w_{l i r} W K_{l i r} L K_{l i r}+\sum_{i} t r_{i r} R_{i r} K_{i r}
\end{aligned}
$$

(27) $S H_{r}=\sum_{h} S_{P_{h r}} \times Y H_{h r}$

(28) $S G_{r}=s_{G_{r}} \times Y G_{r}$ for $r=$ Indonesia

(29) $S_{r}=S H_{r}+S G_{r}$

\section{Consumers}

(30) $C_{i r}=P C M_{i r}$ subs $_{i r}+b s h r_{i r}\left\lfloor\left(1-s_{P_{r}}\right) Y H_{r}-\sum_{i} P C M_{i r} s u b s_{i r}\right\rfloor$

(31) $\left.\quad C_{h i r}=P C M_{i r} s u b s_{h i r}+b s h r_{h i r}\left(1-s_{P_{h r}}\right) Y H_{h r}-\sum_{i} P C M_{i r} s u b s_{h i r}\right\rfloor$

(32) $C_{i r}=\sum_{h} C_{h i r}$

(33) $C_{r}=\sum_{i} C_{i r}$

(34) $P C_{r}=\left(1-s_{P_{r}}\right) Y H_{r} / C_{r}$

\section{Government}

(35) $G_{r}=\left(Y G_{r}-S G_{r}\right) / P G_{r}$

(36) $G_{i r}=\operatorname{cgcf} f_{i r} G_{r}$ 


$$
P G_{r}=\sum_{i} \operatorname{cgcf} f_{i r} P G M_{i r}
$$

\section{External sectors}

(38) $Q_{i r}=\sum_{j} X_{j r}^{S} \times i o c f_{i j r}+C_{i r}+G_{i r}+I D_{i r}+V_{i r}+T M Q_{i r}$ where $Q_{i r}=a_{M_{i r}}\left(\omega_{M_{i r}} M_{i r}^{-\delta_{i r}}+\left(1-\omega_{M_{i r}}\right) D_{i r}^{-\delta_{i r}}\right)^{-1 / \delta_{i r}}$

$$
\begin{aligned}
& D_{i r}=a_{M_{i r}} \delta_{i r} /\left(1+\delta_{i r}\right)\left(\left(1-\omega_{M_{i r}}\right) P_{i r} / P D_{i r}\right)^{1 /\left(1+\delta_{i r}\right)} \times Q_{i r} \\
& \text { (40) } \quad M_{i r}=a_{M_{i r}} \delta_{i r} /\left(1+\delta_{i r}\right)\left(\omega_{M_{i r}} P_{i r} / P M_{i r}\right)^{1 /\left(1+\delta_{i r}\right)} \times Q_{i r}
\end{aligned}
$$

\section{Linkage between Countries or Regions}

(41) $M S_{i r k}=a_{S_{i r}}^{\theta_{i r} /\left(1+\theta_{i r}\right)}\left(\omega_{S_{i r k}} P M S_{i r k} / P M_{i r}\right)^{1 /\left(1+\theta_{i r}\right)} M_{i r}$

(42) $E_{i r}^{S}=\sum_{k} M_{i k r}$

$$
M_{i r}=a_{S_{i r}}\left(\sum_{l} \omega_{S_{i r k}} M S_{i r r^{-i_{r}}}^{-\theta}\right)^{-1 / \theta_{i r}}
$$

(43) $\quad P M \$_{i r k}=P E \$_{i k}\left(1+t m r_{i r k}\right)$

(44) $\quad \sum_{r} F \$_{r}=0$

\section{International transportation services}

$$
\begin{aligned}
& P T M . T M G=\sum_{i r k} \frac{t m r_{i r k}}{1+t m r_{i r k}} P M \$_{i r k} M S_{i r k} \\
& T M Q_{i r}=a_{T}^{\tau /(1+\tau)}\left[\omega_{T_{i r}}\left(P_{i r} / E R_{r}\right) / P T M\right]^{1 /(1+\tau)} T M G \\
& P T M=a_{T}{ }^{-1}\left[\sum_{i r} \omega_{T_{i r}}^{1 /(1+\tau)}\left(P_{i r} / E R_{r}\right)^{\tau /(1+\tau)}\right]^{(1+\tau) / \tau}
\end{aligned}
$$

\section{Capital formation}

(48) $I_{r}^{n}=P I M_{r} I_{r}$

(49) $I D_{i r}=i n v c f_{i r} I_{r}$

(50) $\quad V_{i r}=$ invtr $_{i r} X_{i r}^{S}$

(51) $D E P_{r}=\operatorname{depr}_{r} K_{r}^{S}$

(52) $P I M_{r}=\sum_{i}$ invcf $_{i r} P K M_{i r}$

(53) $P I_{r}=\sum_{i} i_{i n v f} P_{i r}$

\section{International capital mobility}

(54) $R A_{r}=R_{r}^{e} / P I_{r}-$ depr $_{r}$

(55) $R E_{r}=R A_{r}\left(K_{r}^{S} / K L A G_{r}^{S}\right)^{\phi}$

(56) $R E_{r}=\operatorname{recf}_{r} R G E$

(57) $K_{r}^{S}=K L A G_{r}^{S}-D E P_{r}+I_{r}$ 


\section{GDP Indentities}

(58) $G D P R_{r}=\sum_{i} C_{i r} P C M 0_{i r}+\sum_{i} G_{i r} P G M 0_{i r}+\sum_{i} i o c f_{i j r} X_{j r} P N M 0_{i r}$

$$
\sum_{i} V_{i r} P X 0_{i r}+\sum_{i} I D_{i r} P K M 0_{i r}-
$$

$\sum_{i k} M S_{i r k} P M \$ 0_{i r k} E R 0_{r}+\sum_{i} E_{i r} P E \$ 0_{i r} E R 0_{r}$

(59) $G D P N_{r}=\sum_{i} C_{i r} P C M_{i r}+\sum_{i} G_{i r} P G M_{i r}+\sum_{i} i o c f_{i j r} X_{j r} P N M_{i r}$

$$
\sum_{i} V_{i r} P X_{i r}+\sum_{i} I D_{i r} P K M_{i r}-
$$

$$
\sum_{i k} M S_{i r k} P M \$_{i r k} E R_{r}+\sum_{i} E_{i r} P E \$_{i r} E R_{r}
$$

\section{Equilibrium conditions}

$$
\begin{aligned}
& \sum_{i} K_{i r}=K_{r}^{S} \\
& \sum_{i} L_{l i r}=\overline{L_{l r}^{S}} \\
& D_{i r}^{S}=D_{i r} \\
& \sum_{i k} M S_{i r k} \times P M \$_{i r k}-\sum_{i} E_{i r} P E \$_{i r}-\sum_{i} T M Q_{i r} P_{i r} / E R_{r}-F \$_{r}=0
\end{aligned}
$$

\section{Walrasian law}

\section{Local:}

$$
\begin{aligned}
& \sum_{i} P D_{i r} \times\left(D_{i r}-D_{i r}^{S}\right)+\left(S_{r}+F_{r}-I_{r}^{n}-\sum_{i} P_{i r} \times V_{i r}\right) \\
& \quad+E R_{r} \times\left(\sum_{i k} M S_{i r k} \times P M \$_{i r k}-\sum_{i} E_{i r} P E \$_{i r}-T M Q_{i^{\prime} r} P_{i^{\prime} r} / E R_{r}-F \$_{r}\right)=0
\end{aligned}
$$

Global:

$$
\begin{aligned}
& \sum_{r} \sum_{i} P D_{r} \times\left(D_{i r}-D_{i r}^{S}\right) / E R_{r}+\sum_{r}\left(S_{r}+F_{r}-I_{r}^{n}-\sum_{r} P_{i r} \times V_{i r}\right) / E R_{r} \\
& +\sum_{r i} P E \$_{i r}\left(\sum_{k} M S_{i r k}-E_{i r}\right)+\left(P T M \times T M G-\sum_{r}\left(P_{i^{\prime} r} / E R_{r}\right) T M Q_{i^{\prime} r}\right)-\sum_{r} F \$_{r}=0
\end{aligned}
$$

N.B. $\sum_{r} F \$_{r}=0$ if $\sum_{r i}\left(\sum_{k} M S_{i r k}-E_{i r}\right)=0$ and $P T M \times T M G=\sum_{r}\left(P_{i^{\prime} r} / E R_{r}\right) T M Q_{i^{\prime r} r}$

\section{B2. Model Notation}

\section{Sets}

$\mathrm{i}, \mathrm{j} \quad$ industries

$\mathrm{r}, \mathrm{k} \quad$ countries or regions

1 labor types

h households

Price Variables

$P M \$_{i r k} \quad$ world price of imports

$P M S_{\text {irk }} \quad$ domestic prices of imports by sources of imports

$P M_{i r} \quad$ domestic prices of imports 
$P E \$_{i r} \quad$ world price of exports

$P E_{i r} \quad$ domestic prices of exports

$P X_{i r} \quad$ output prices

$P D_{i r} \quad$ domestic prices of domestically produced products

$P_{i r} \quad$ prices of composite goods

$P N_{i} \quad$ value added prices by sectors

$P C M_{i r} \quad$ market prices of consumer's goods

$P G M_{i r} \quad$ market prices of public goods

$P N M_{i r} \quad$ market prices of intermediate inputs

$P K M_{i r} \quad$ market prices of capital goods

$P I_{r} \quad$ investment price index

$P I M_{r} \quad$ investment price index

$P C_{r} \quad$ consumer price index

$P G_{r} \quad$ price index of public goods

PTM composite price of international transportation services

$W_{i r} \quad$ wage rates by sectors

$W K_{l i r} \quad$ wage rates by sectors and types of labor

$W M_{i r} \quad$ composite market wage rates

$W K M_{\text {lir }} \quad$ composite market wage rates by sectors and types of labor

$W K_{l r}^{e} \quad$ equilibrium wage rates by types of labor

$R_{i r} \quad$ capital rents

$R M_{i r} \quad$ market capital rents

$R_{r}^{e} \quad$ equilibrium capital rent

$R A_{r} \quad$ net real rate of return to capital

$R E_{r} \quad$ expected rate of return to capital

$R G E \quad$ global expected rate of return to capital

$E R_{r} \quad$ exchange rate

\section{Quantity variables}

$X_{i r}^{S} \quad$ domestic output

$L_{i r} \quad$ composite labor demand

$L K_{l i r} \quad$ labor demand by types of labor

$\overline{L_{l r}^{S}} \quad$ supply of labor by types

$K_{i r} \quad$ capital demand by sector

$K_{r}^{S} \quad$ total supply of capital

$K L A G_{r}^{S} \quad$ total capital stock in the previous period

$Q_{i r} \quad$ composite good demand 
$D_{i r} \quad$ domestic supply of domestically produced products

$E_{i r} \quad$ export supply

$M_{i r} \quad$ imports

$M S_{i r} \quad$ imports by country of origin

$T M G \quad$ total demand for international transportation services

$T M Q_{i r} \quad$ demand for international transportation services by countries and regions

$C_{i r} \quad$ household consumption by sectors

$C_{h i r} \quad$ household consumption by sectors and households (Indonesia)

$C_{r} \quad$ total demand for household consumption

$G_{i r} \quad$ demand for government consumption

$G_{r} \quad$ total demand for government consumption

$F \$_{r} \quad$ foreign savings

$I_{r} \quad$ total real fixed investment

$I D_{i r} \quad$ demand for capital goods

$V_{i r} \quad$ demand for inventory investment

$D E P_{r} \quad$ total depreciation expenditure

$G D P R_{r} \quad$ real GDP by countries

\section{Nominal variables}

$\mathrm{YH}_{r} \quad$ household income

$Y_{h r} \quad$ household income (Indonesia)

$Y G_{r} \quad$ government revenue

$\mathrm{SH}_{r} \quad$ household savings

$S G_{r} \quad$ government savings

$S_{r} \quad$ domestic savings

$I_{r}^{n} \quad$ nominal fixed investment

$G D P N_{r} \quad$ nominal GDP by countries

\section{Parameters}

$a_{X_{i r}}$

$\omega_{X_{i r}}$

$\rho_{i r}$

$a_{L_{i r}}$

$\omega_{L_{\text {lir }}}$

$\lambda_{i r}$

$a_{M_{i r}}$

$\omega_{M_{i r}}$ scale parameters in production functions

share parameters in production functions

exponent parameters in production functions

scale parameters in labor demand functions

share parameters in labor demand functions

exponents in labor demand functions

scale parameters in composite goods functions

share parameters in composite goods functions 


$\begin{array}{ll}\delta_{i r} & \text { exponents in composite goods functions } \\ a_{S_{i r}} & \text { scale parameters in import demand functions } \\ \omega_{S_{i k r}} & \text { share parameters in import demand functions } \\ \theta_{i r} & \text { exponents in import demand functions } \\ a_{E_{i r}} & \text { scale parameters in export supply functions } \\ \omega_{E_{i r}} & \text { share parameters in export supply functions } \\ \gamma_{i r} & \text { exponents in export supply functions } \\ a_{T} & \text { scale parameters in the demand functions for transportation services } \\ \omega_{T_{i r}} & \text { share parameters in the demand functions for transportation services } \\ \tau & \text { exponents in the demand functions for transportation services } \\ i o c f_{i j r} & \text { intermediate input coefficient of good } \mathrm{j} \text { in industry i } \\ y k c f_{h i r} & \text { share of capital income accrued to household h } \\ y l c f_{h i r} & \text { share of labor income accrued to household h } \\ s u b s_{i r} & \text { subsistence consumption (for other countries rather than Indonesia) } \\ s u b s_{h i r} & \text { subsistence consumption (for Indonesia) } \\ b s h r_{i r}, b s h r_{h i r} & \text { marginal budget shares } \\ c g c f_{i r} & \text { government consumption shares } \\ i n v c f_{i r} & \text { fixed investment shares } \\ i n v t t_{i r} & \text { ratios of inventory investment to real production } \\ S_{P_{r}}, s_{P_{h r}} & \text { private saving rate } \\ S_{G_{r}} & \text { government saving rate } \\ t m_{i r} & \text { import tariff rates } \\ t e_{i r} & \text { export duty rates } \\ t c_{i r} & \text { sale taxes on consumers' goods } \\ t g_{i r} & \text { sale taxes on public goods } \\ t n_{i j r} & \text { sale taxes on intermediate inputs } \\ t k_{i r} & \text { sale taxes on capital goods } \\ t p_{i r} & \text { production taxes/subsidies } \\ t w_{l i r} & \text { labor taxes/subsidies } \\ t r_{i r} & \text { capital taxes/subsidies } \\ \end{array}$

